\title{
Peritoneal Cryptococcosis in a Dog
}

\author{
Beline Mergulhão de Oliveira Carvalho da Silva' ${ }^{1}$ Natália Freitas de Souza ${ }^{2}$ \& \\ Washington Luiz Assunção Pereira' ${ }^{1}$
}

\begin{abstract}
Background: Cryptococcosis is an opportunistic, systemic mycotic disease caused by yeasts of genus Cryptococcus. Cryptococcus neoformans might cause serious public health problems, as they can be transmitted to humans, domestic and wild animals. In cats and dogs, the main site of infection is the upper lower respiratory tract, however, the infection can extend and affect other sites in the organism, however, the peritoneal manifestation of the disease is rare. Thus, the present work aims to report a case of cryptococcosis in a canine, mixed breed, female, adult, from the Metropolitan Region of Belém, PA, Brazil.

Case: A mixed breed dog, female, adult was admitted in a veterinary hospital at Belém, presenting abdominal discomfort and, after the clinical examination, emergency exploratory laparotomy was indicated, and it were observed disseminated lesions in the abdominal cavity, with multiple nodules attached to the peritoneum and intestinal serosa and bladder, uterus, among other organs. Fragments from the surgical biopsy were fixed, and processed routinely according to the techniques for histological tissue processing. Histological examination revealed a predominance of granulomatous lesions in peritoneum and mesentery organs. It was observed a discrete inflammatory reaction of macrophages, epithelioid cells and giant cells, many in phagocytosis of spherical or ovoid organisms, with a thick capsule and a clear perinuclear halo. In the PAS staining, the Cryptococcus conidia presented eosinophilic characteristics and some of them had the capsule well demarcated, which was shown to be radiated. Also it was possible to see the budding yeast and in the Grocott stain, the Cryptococcus stained in black.

Discussion: Cryptococcosis with peritoneal involvement in animals is rarely reported in the literature. Cryptococcus is a fungus that presents tropism by the central nervous system and nasal cavity, however atypical presentations have been reported, especially at the level of the abdominal cavity (intestines and mesentery). It is believed that the gastrointestinal tract is the gateway for ascending contamination, or that the contamination can occur by fungal ingestion. The lesions presented a multiple distribution, with isolated and coalescent nodules adhered to the peritoneum and adjacent structures. The literature reports two cases of dogs with intra-abdominal cryptococcosis, in which, macroscopically, granulomatous formations were observed in the jejunum, with lymph nodes and mesentery. Microscopically, a discrete inflammatory infiltrate of macrophages and lymphocytes were observed. Some areas with granulomatous reaction, lymphocytes, epithelioid macrophages and giant cells and, in other areas, yeasts in the cytoplasm were observed. The yeasts were spherical or ovoid, surrounded by a thick capsule of polysaccharide. The periodic acid Schiff (PAS) and silver impregnation (Grocott) staining were used to highlight structures of the Cryptococcus wall which were presented by a strong stained polysaccharide capsule. It must be emphasized the zoonotic potential of cryptococcosis, a disease that can affect both animals and humans. Cryptococcosis in humans normally occurs when the fungus accesses the airways through inhalation and ranges from asymptomatic pulmonary colonization to compromised meninges, causing the human patient's life-threatening condition. In the present report, the diagnosis of cryptococcosis was established through histopathological and histochemical examination of the fungal structure, which were determinant in the etiological diagnosis of cryptococcosis.
\end{abstract}

Keywords: peritoneum, Cryptococcus spp., canine, mycotic granuloma. 


\section{INTRODUCTION}

Cryptococcosis is an opportunistic, systemic mycotic disease caused by Cryptococcus spp. yeast of Cryptococcus neoformans. Infection in dogs most commonly occurs through inhalation of yeasts or spores [11]. The yeast has two varieties: $C$. neoformans var. neoformans and var. gattii. These pathogens cause serious public health problems, as they can be transmitted to humans, domestic and wild animals [12].

Cryptococcus neoformans var. neoformans are common in dogs but appear to be rare in cats, according to studies in California, USA. The C. neoformans var. gatti has been associated with tropical and subtropical climates; it can be isolated from contaminated soil, fresh water and in the air, which represents a risk of infection not only for dogs and cats but also humans [20]. The infection often develops in immunosuppressed animals, animals that are debilitated or in malnutrition cases [19].

Cryptococcosis is frequently observed in humans and domestic animals, especially cats, farm animals and, seldom, wild animals [14]. In cats and dogs, the main site of infection is the upper lower respiratory tract, however, the infection can extend locally and affect the central nervous system as well as the lower respiratory tract and adjacent tissues such as regional lymph nodes [13].

Although the respiratory tract is considered to be the usual gateway to the body, the gastrointestinal tract can also be a potential site of entry [3], causing peritoneal cryptococcosis, a rare manifestation of the disease. Thus, the present study aims to report a case of peritonitis by Cryptococcus in a canine and discuss anatomopathological aspects of the disease.

\section{CASE}

The Veterinary Hospital Professor Mário Dias Teixeira (HOVET), from the Federal Rural University of the Amazon - UFRA treated a mixed breed dog, female, adult, from the Metropolitan Region of Belém, State of Pará. During the physical examination, the animal had abdominal discomfort and, after the clinical examination, emergency exploratory laparotomy was indicated.

During surgery, it was observed disseminated lesions in the abdominal cavity, with multiple nodules attached to the peritoneum and intestinal serosa and bladder (Figure 1A and 1B), uterus, among other organs. Samples were collected and sent to the Animal Pathology Laboratory at UFRA, for anatomo-pathological examination. Due to the severity of the condition, the animal was euthanized, which was authorized by the owner, however, the owner did not authorize the performance of the necroscopic examination.

Fragments from the surgical biopsy were fixed in $10 \%$ buffered formalin, and processed routinely according to the techniques for histological tissue processing, which consist of dehydration, diaphanization and impregnation with paraffin and subsequent inclusion in paraffin blocks. For analysis, $4 \mu \mathrm{m}$ sections were made and stained with hematoxylin and eosin (HE). In addition, histochemical techniques staining with periodic acid Schiff (PAS) and silver impregnation with Grocott's staining were used to evidence the fungal cell wall.

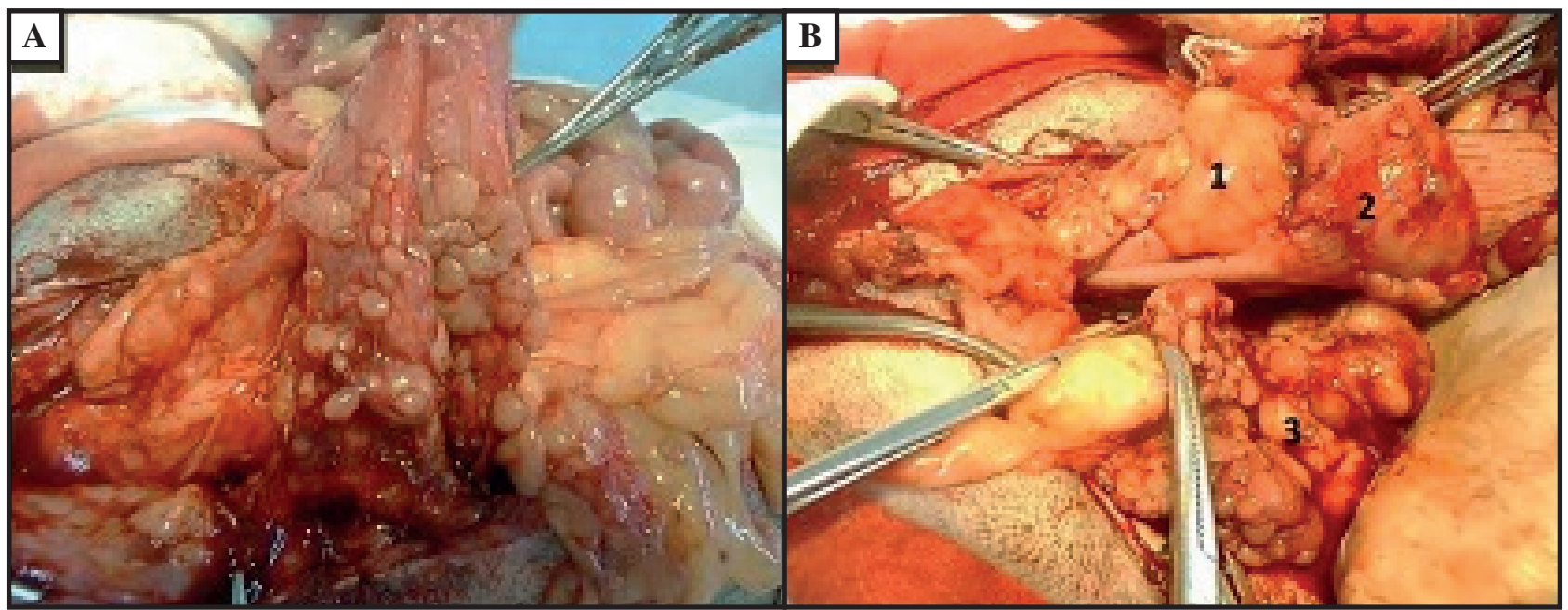

Figure 1. Canine peritoneal cryptococcosis. A- Gross lesion with multiple nodules, mostly coalescent. B- Intestinal (1), bladder (2) serosa manifestation with large peritoneal masses (3). 
Histological examination revealed a predominance of granulomatous lesions (cryptococomas) in peritoneum and mesentery organs, represented by multiple to coalescent hypodense nodulations (Figure 2A). It was observed a discrete inflammatory reaction of macrophages, epithelioid cells and giant cells, many in phagocytosis of spherical or ovoid organisms, with a thick capsule and a clear perinuclear halo (Figure 2B), besides occasional lymphocytes.

In the PAS staining, the Cryptococcus conidia presented eosinophilic characteristics and some of them had the capsule demarcated, which was shown to be radiated. Also it was possible to see the budding yeast (Figure 2C), and in the Grocott stain, the Cryptococcus stained in black (Figure 2D).

\section{DISCUSSION}

Reports have shown that the disease is prevalent in animals of approximately two years with no predilection for sex or race [9]. However, subsequent studies have reported the appearance of peritoneal cryptococcosis in Boxer, Schnauzer, Border Collie breeds, between 14 months and four years old [11]. It is noteworthy that the disease is uncommon and, in the clinical approach, most of the time, it is not considered as the first diagnosis [5].

Cryptococcosis with peritoneal involvement in animals is rarely reported in the literature. Cryptococcus is an agent that presents tropism by the central nervous system and nasal cavity, however atypical presentations have been reported, especially at the level of the abdominal cavity (intestines and mesentery) $[9,10,16]$, similar to this report.

It is believed that the gastrointestinal tract is the gateway for ascending contamination, or that the contamination can occur by fungal ingestion. A case of canine cryptococcosis with intestinal involvement was described by Oliveira et al. [16] and the authors

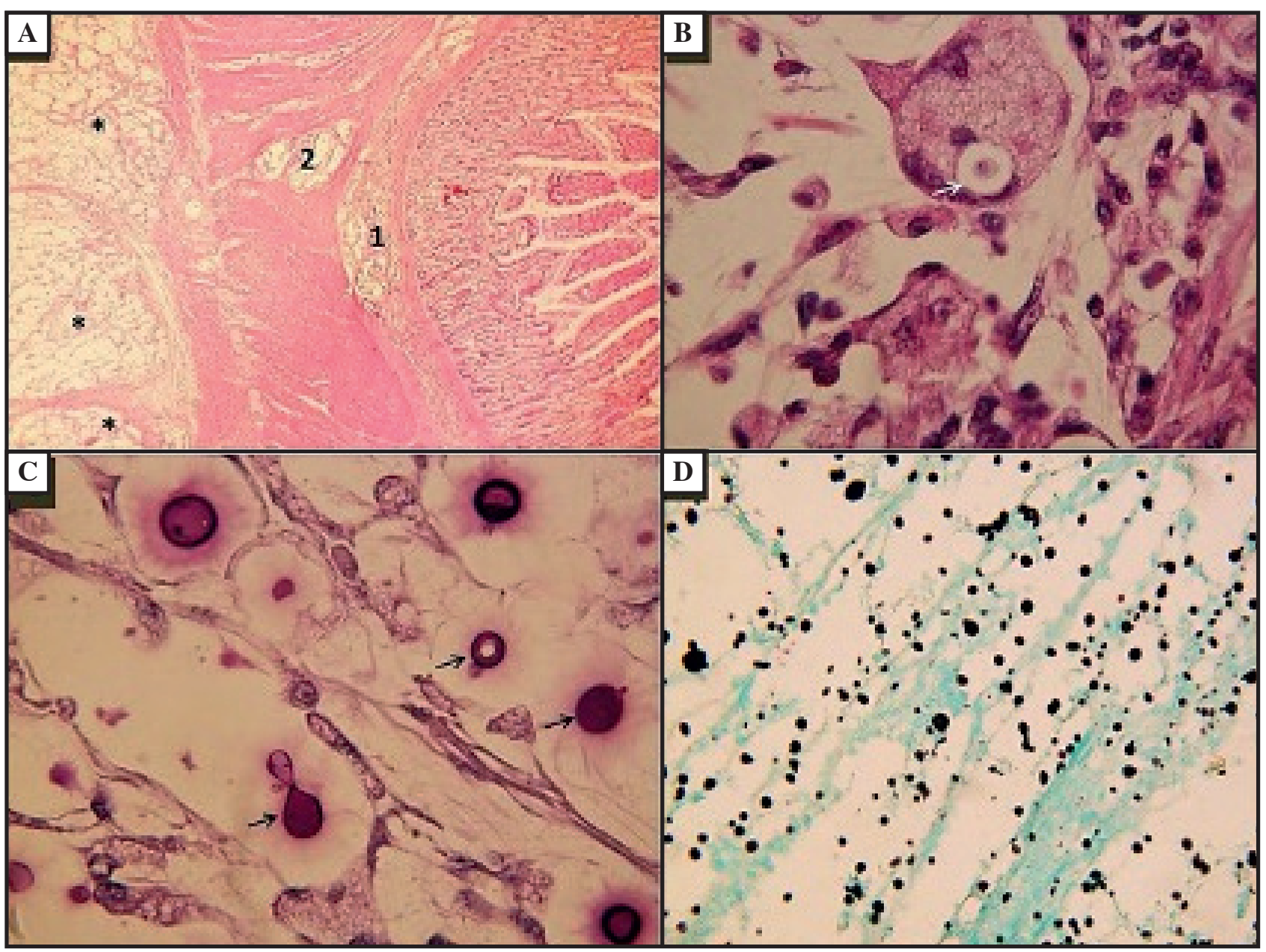

Figure 2. Photomicrographs of peritoneal cryptococcosis. A- Photomicrography of the intestine presenting multiple nodules in the serosa (*) and submucosa (1) and muscle (2) [HE; Obj.4x]. B- Reaction with macrophages, including a giant cell phagocyting Cryptococcus blastoconidia (arrow) [HE; Obj.40x]. C- Cryptococcus blastoconidia, some in budding [PAS; Obj.10x]. D- Positive Grocott stain, showing abundant presence of Cryptococcus blastoconidia [Obj 4x]. 
reported that the infection may have started from a previous injury, and that it was a gateway for the fungus. Another possibility was the ingestion of dried yeast.

The lesions presented a multiple distribution, with isolated and coalescent nodules adhered to the peritoneum and adjacent structures, which are similar to the presentation previously described by Malik et al. [10]. These authors reported two cases of dogs with intra-abdominal cryptococcosis, in which, macroscopically, granulomatous formations were observed in the jejunum, with lymph nodes and mesentery. Pereira et al. [18] described a case in a canine, which presented nodules of different diameters in various areas of the body, as a result of systemic dissemination. In the present study, the necroscopy was not performed, making impossible to verify the systemic effects of the disease.

Microscopically, a discrete inflammatory infiltrate of macrophages and lymphocytes were observed. Some areas with granulomatous reaction, lymphocytes, epithelioid macrophages and giant cells and, in other areas, yeasts in the cytoplasm were observed [7]. The yeasts were spherical or ovoid, surrounded by a thick capsule of polysaccharide. The morphological characteristics are similar to those described in several studies being compatible with Cryptococcus $[4,7,8,16,17]$.

The periodic acid Schiff (PAS) and silver impregnation (Grocott) staining were used to highlight structures of the Cryptococcus wall which presented by a strong stained polysaccharide capsule, a characteristic that differentiates it from other systemic mycoses $[4,16]$. It must be emphasized the zoonotic potential of cryptococcosis, a disease that can affect both animals and humans. In the State of Pará, a study performed at an hospital in the city of Belém, between 1992 and 1998, diagnosed 78 cases of cryptococcosis. This result demonstrates that the State of Pará is endemic to Cryptococcus infection [2]. Cryptococcosis in humans normally occurs when the fungus accesses the airways through inhalation and ranges from asymptomatic pulmonary colonization to compromised meninges, causing the human patient's life-threatening [15].

In the present report, the diagnosis of cryptococcosis was established through histopathological and histochemical examination of the fungal structure, which were determinant in the etiological diagnosis of cryptococcosis [1]. The clinical signs were nonspecific and the characteristics of the macroscopic lesions allow only the presumptive diagnosis [6]. In addition, studies about Cryptococcus and its atypical presentation are important to minimize the incidence of this fungal infection, which has a zoonotic potential, affecting both humans and animals.

Declaration of interest. The authors report no conflicts of interest. The authors alone are responsible for the content and writing of the paper.

\section{REFERENCES}

1 Bazzi T., Melo S.M.P., Fighera R.A. \& Kommers G.D. 2016. Características clínico-epidemiológicas, histomorfológicas e histoquímicas da esporotricose felina. Pesquisa Veterinária Brasileira. 36(4): 303-311. DOI: 10.1590/ S0100-736X2016000400009.

2 Corrêa M.P.S.C., Oliveira E.C., Duarte R.R.B.S., Pardal P.P.O., Oliveira F.M. \& Severo L.C. 1999. Criptococose em crianças no Estado do Pará, Brasil. Revista da Sociedade Brasileira de Medicina Tropical. Brasília (DF). 32(5): 505-508. DOI: 10.1590/S0037-86821999000500006.

3 El-kersh K., Rawasia W.F., Chaddha U. \& Guardiola J. 2013. Rarity revisited: cryptococcal peritonitis. BMJ Case Report. 10: 1-4. DOI: 10.1136/bcr-2013-009099.

4 Galiza G.J.N., Silva T.M., Caprioli R.A., Tochetto C., Rosa F.B., Fighera R.A. \& Kommers G.D. 2014. Características histomorfológicas e histoquímicas determinantes no diagnóstico da criptococose em animais de companhia. Pesquisa Veterinária Brasileira. 34(3): 261-269. DOI: 10.1590/S0100-736X2014000300011.

5 Gonçalves S.R.F., Silva O.P., Barretto M.L.M., Dias R.F.F., Oliveira R.P., Silva G. G., Albuquerque P.P.F., Pereira M.F. \& Oliveira A.A.F. 2018. Systemic Cryptococcosis in a Miniature Shnauzer Dog. Acta Scientiae Veterinariae. 46(5 Supp11): 300. DOI: 10.22456/1679-9216.86857.

6 Jensen H.E., Schonheyder H.C., Hotchi M. \& Kaufman L. 1996. Diagnosis of systemic mycoses by specific immunohistochemical tests. APMIS. 104(4): 241-258. DOI: 10.1111/j.1699-0463.1996.tb00714.x.

7 Kommers G.D., Souza T.M., Souto M.A.M., La Corte F.D. \& Barros C.S.L. 2005. Criptococose pulmonar granulomatosa em um equino. Ciência Rural. 35(4): 938-940. DOI: 10.1590/S0103-84782005000400032. 
8 Lima P.Q., Oliveira F.P. \& Marciano J.A. 2018. Criptococose em gato - relato de caso. Revista Científica de Medicina Veterinária. 30(10): 1-10.

9 Malik R., Dill-Macky E., Martin P., Wigney D.I., Muir D.B. \& Love D.N. 1995. Cryptococcosis in dogs: a retrospective study of 20 consecutive cases. Journal Medical Veterinary Mycology. 33(5): 291-297. DOI: 10.1080/02681219580000601.

10 Malik R., Hunt G.B., Bellenger C.R., Allan G.S., Martin P., Canfield P.J. \& Love D.N. 1999. Intra-abdominal cryptococcosis in two dogs. Journal of Small Animal Practice. 40(8): 387-391. DOI: 10.1111/j.1748-5827.1999. tb03106.x.

11 Marcasso R.A., Sierra S., Arias M.V.B., Bracarense A.P.F.R.I., Yamamura A.A.M., Biasi F., Lopes B.A., Amude A.M. \& Cortêz D.E.A. 2005. Criptococose no sistema nervoso de cães - relato de três casos. Semina: Ciências Agrárias. 26(2): 229-238. DOI: 10.5433/1679-0359.2005v26n2p229.

12 Marinho M., Táparo C.V., Silva B.G., Tencate L.N. \& Perri S.L.V. 2010. Microbiota fúngica de passeriformes de cativeiros da região noroeste do Estado de São Paulo. Veterinária e Zootecnia. 17(2): 288-292.

13 Mcgill S., Malik R., Saul N., Beetson S., Secombe C., Robertson I. \& Irwin P. 2009. Cryptococcosis in domestic animals in Western Australia: a retrospective study from 1995-2006. Medical Mycology. 47(6): 625-639. DOI: 10.1080/13693780802512519.

14 Müller M. \& Nishizawa M. 2017. A criptococose e sua importância na Medicina Veterinária. Revista de Educação Continuada em Medicina Veterinária e Zootecnia do CRMV-SP. 15(1): 24-29. DOI: 10.36440/recmvz.v15i1.36761.

15 Nadrous H.F., Antonios V.S., Terrell C.L. \& Ryu J.H. 2003. Pulmonary cryptococcosis in non-immunocompromised patients. Chest. 124(6): 2143-2147. DOI: 10.1016/S0012-3692(15)31671-8

16 Oliveira M.C., Stocco A.V., Silva S.C., Sousa C.A.S., Moreira R.M. \& Figueiredo M.A. 2017. Criptococose intestinal em um cão: relato de caso. Revista Brasileira de Ciência Veterinária. 24(3): 128-131. DOI: 10.4322/rbcv.2017.025.

17 Pedroso R.S. 2004. Cryptococcus spp de fontes ambientais em Ribeirão Preto: ocorrência, fatores de virulência e sensibilidade aos antifúngicos. Ribeirão Preto, SP. Dissertação (Mestrado) - Faculdade de Ciências Farmacêuticas de Ribeirão Preto, Universidade de São Paulo.

18 Pereira M.F., Santos B.M., Silva V.C.L., Pereira H.N.S., Silva L.B.G., Paiva B.H.A., Barros R.B., Dias M.B.M.C., Neves A.K.R. \& Oliveira A.A.F. 2013. Aspectos clínicos e anatomopatológicos da criptococose nasal com disseminação sistêmica em cão: relato de caso. Medicina Veterinária (UFRPE). 7(2): 7-15.

19 Queiroz J.P.A.F., Sousa F.D.N., Lage R.A., Izael M.A. \& Santos A.G. 2008. Criptococose - uma revisão bibliográfica. Acta Veterinaria Brasilica. 2(2): 32-38. DOI:10.21708/avb.2008.2.2.699.

20 Sykes J.E. \& Malik R. 2012. Cryptococcosis. In: Greene C.E. (Ed). Infectious Diseases of Dog and Cat. 4th edn. Saint Louis: Elsevier Saunders, pp.621-634. 